GEOLOGICAL SURVEY CIRCULAR 797

A Preliminary Study

of the Santa Barbara, California,

Earthquake of August 13, 1978

and its Major Aftershocks 



\section{A Preliminary Study of the Santa Barbara, California, Earthquake of August 13, 1978 and its Major Aftershocks}

By W. H. K. Lee, C. E. Johnson, T. L. Henyey, and R. L. Yerkes

$\begin{array}{llll}\text { GEOLOGICAL SURVEY CIRCULAR } & 797\end{array}$




\section{United States Department of the Interior}

CECIL D. ANDRUS, Secretary

\section{Geological Survey}

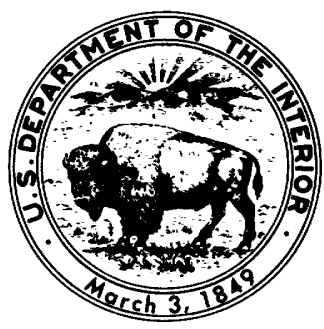

H. William Menard, Director

Library of Congress catalog-card No. 78-600153 


\section{CONTENTS}

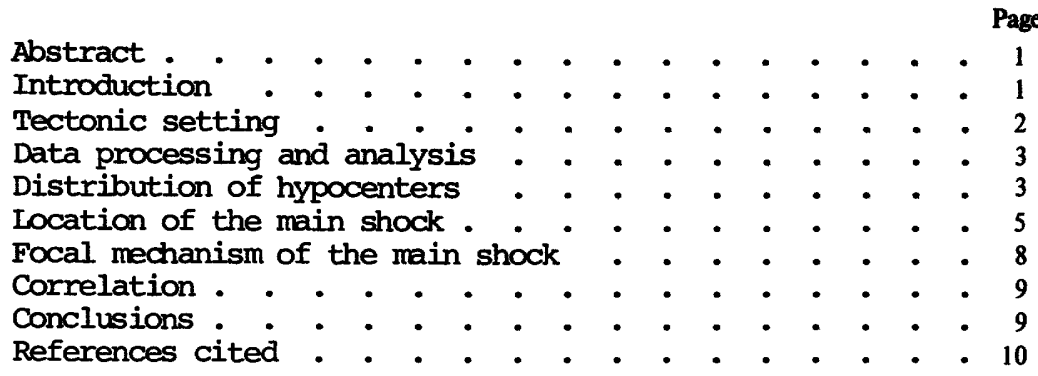

\section{ILLUSTRATIONS}

Figure 1. Map showing locations of principal seismograph

Page stations and major earthquakes in Santa

Barbara channel . . . . . . . . . . 2

2. Diagram showing crustal structure models . - 5

3. Map showing epicenters of Santa Barbara earthquake and its major aftershocks . . . 8

4. Diagram showing fault-plane solution of Santa Barbara earthquake . . . . . . . 9

5. Cross section of area of figure 3 showing hypocenter distribution and faults . . . 10

\section{TABLES}

Table 1. Coordinates and delays of principal seismographic stations used in the present study . . 4

2. List of Santa Barbara earthquakes, August

3. Criteria for the four quality grades of $Q^{\circ} \cdot \frac{1}{13}-8$ 


\title{
A Preliminary Study of the Santa Barbara, California, Earthquake of August 13, 1978 and its Major Aftershocks
}

\author{
By W. H. K. Lee, C. E. Johnson, T. L. Henyey, and R. L. Yerkes
}

\begin{abstract}
The M 5.I Santa Barbara earthquake of August 13,1978 occurred at lat $34^{\circ} 22.2^{\prime} \mathrm{N}$., long $119^{\circ} 43.0^{\prime} 4 \mathrm{~km}$ south of Santa Barbara, Calif. at a depth of $12.5 \mathrm{~km}$ in the northeast Santa Barbara Channel, part of the western Transverse Ranges geomorphic-structural province. This part of the province is characterized by seismically active, east-trending reverse faults and rates of coastal uplift that have averaged up to about $10 \mathrm{~m} / 1000$ years over the last 45,000 years.

No surface muture was detected onshore. Subsurface rupture propagated northwest from the main shock toward Goleta, $15 \mathrm{~km}$ west of Santa Barbara, where a maximum acceleration of $0.44 \mathrm{~g}$ was measured at ground level and extensive minor damage occurred; only minor injuries were reported. A fairly well-constrained faultplane solution of the main shock and distribution of the aftershocks indicate that leftreverse-oblique slip occurred on west-northwesttrending, north-dipping reverse faults; inadequate dip control precludes good correlation with any one of several mapped faults. Had the earthquake been larger and rupture propagated to the southeast or a greater distance to the northwest, it could have posed a hazard to oilfield operations. The fault-plane solution and aftershock pattern closely fit the model of regional deformation and the solution closely resembles those of five previously mapped events located within a $15-\mathrm{km}$ radius.
\end{abstract}

\section{INTRODUCTION}

A moderate-sized earthquake ( $M_{L}=5.1$, an average from five Wood-Anderson stations operated by the Califormia Institute of Technology) occurred $4 \mathrm{~km}$ offshore of Santa Barbara, California at 3:54 p.m. local time (2254 GCT) on the 13th of August, 1978. Minor local damage occurred at the city of Santa Barbara; the campus of the University of Califormia at Goleta
$15 \mathrm{~km}$ to the west suffered extensive minor damage. Hospitals treated scores of people for minor injuries; no major injuries were jeported. This report summarizes the preliminary jesults of our investigation of the main shock and the major aftershocks that occurred in the following five days.

The Santa Barbara Channel region is one of the most active seismic areas of California. The earliest recorded destructive earthorlake, on December 21, 1812, heavily damaged several missions along the coast and had an estjmated magnitude of 7. Since then, numerous erents have been felt and several damaging earthquakes have occurred. In particular, almost the entire business section of Santa Barbara was destroyed or rendered unsafe by the Jume 29, 1925 earthquake of magnitude 6.3. Santa Barbara a.lso was damaged by the Jume 30,1941 earthquake of magnitude 6. These two earthquakes are poorly located but are inferred to have occurred very near to the August 13, 1978 event (fig. 1). A list of significant earthquakes in the santa Barbara Channel area was prepared by Harilton and others (1969) and later revised by Iee and Ellsworth (1975).

With increasing population along tre coast and extensive petroleum development in the Santa Barbara Channel, even moderate-sized earthquakes may be hazardous. Lee and E11sworth (1075) argued that tectonic conditions in the channel region are capable of generating an earthquake as large as magnitude 7.5. In view of the continuing likelihood that a large earthquake will occur in the Santa Barbara Channel, a mejor concern is the correlation of seismic data with recognized faults.

Acknowledgments. - We thank Larry Porter and Tom Wootton of the California Division of Mines and Geology and Gerry Brady of the U.S. Geological Survey for providing strong-motion data. We are grateful to Mari Gunn and Al Walter for assistance in data processing, to Bob Burford and Gary Fuis for their stimulating discussions, and to Peter Ieary, John McRaney and Derek Monov for their tireless efforts in the speedr proc- 


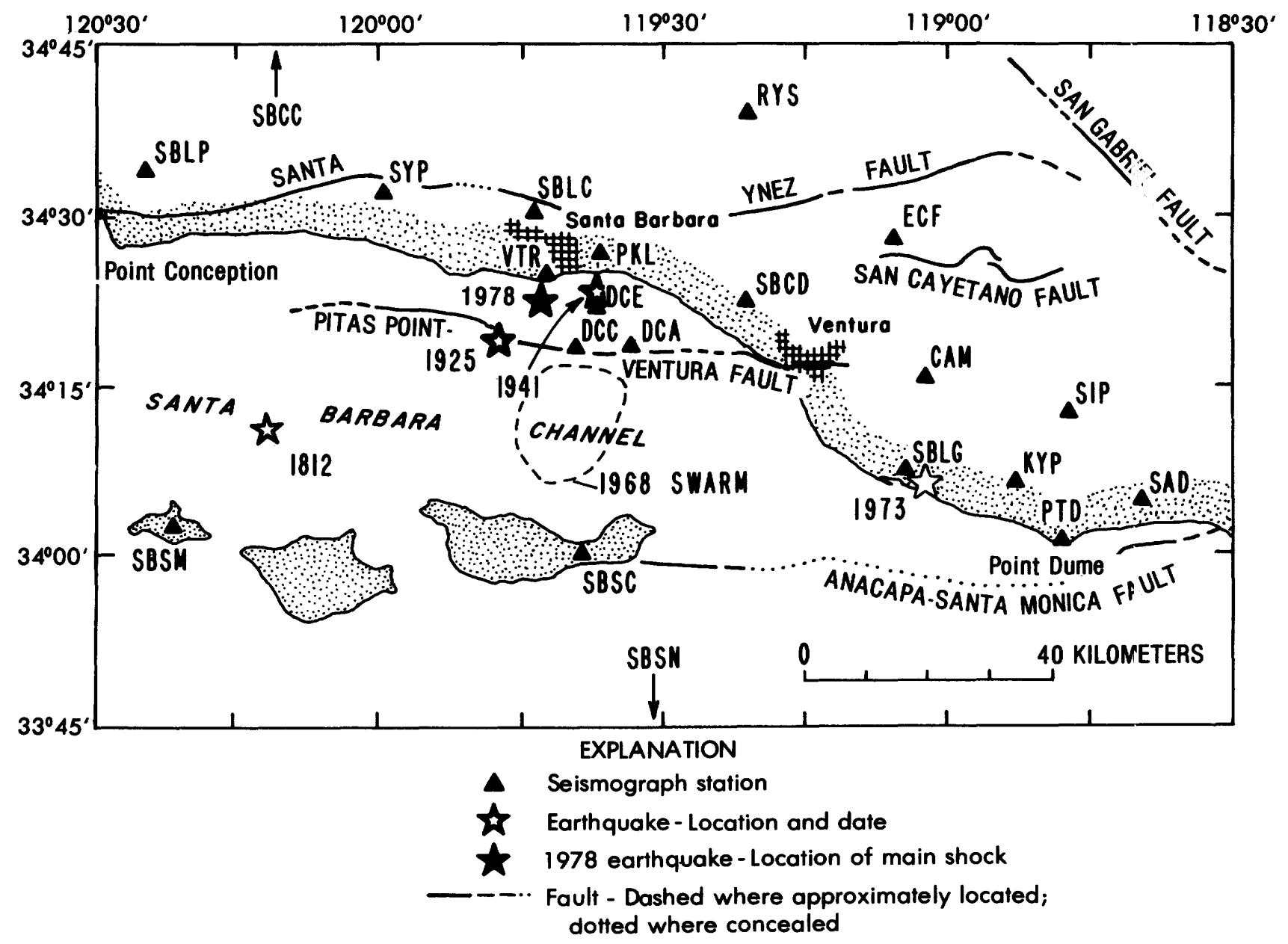

Figure 1.-Locations of principal seismograph stations and major earthquakes in Santa Barbara Channel.

essing of the USC data. The USC Santa Barbara network is supported by the Conservation Divi-sion, U.S. Geological Survey.

\section{TECTONIC SETTING}

Santa Barbara Channel occupies the southwest quarter of the western Transverse Ranges, a geomorphic-structural province of southern California. Relative to adjoining terrain, the Transverse Ranges are unique in several important respects: the distinct east-west orientation, the type, age, and history of exposed basement rocks, and the spectacular rates of compressive deformation as indicated by the imposing reverse-fault-controlled mountain fronts and the extremely deep basins filled with young, intensely deformed sediments (the Santa Barbara Channel-Ventura basin axis is coincident with the steepest known gravity gradient in California).

The western Transverse Ranges are bounded by major faults: the east-trending Santa Ynez on the north, the southeast-trending San Gabriel on the east, and the east-trending Aracapa-Santa Monica on the south. Onshore segments of each of these faults juxtapose dissimilar basement rocks: the Santa Ynez forms the south boundary of the central coast Franciscan, the San Gabriel forms the southwest boundary of exposied Precambrian anorthosites of the western Sar Gabriel Mountains, and the Malibu Coast-Santa Monica forms the north boundary of the western Los Angeles basin-continental borderland Franciscan terrane.

The structure of the western Transverse Ranges is dominated by east-trending reverse faults; one of the best known of these is the Red Mountain fault. Well data, geolc xic mapping, and several congruent fault-plane solutions show that the fault dips northward at about $60^{\circ}$, offsets strata as young as about 500,000 years, and has a maximm stratigraphic separaticn of about $7,500 \mathrm{~m}$ (Yeats and others, in press).

A band of moderate seismicity is associated with some of the east-trending revers? faults 
within the western Transverse Ranges. This result is based on a systematic study of the 6year (1970-1975) record of seismographic stations operated by the U.S. Geological Survey, California Institute of Technology, University of Southern California, and California Department of Water Resources (Lee and others, in press). One or more of about 200 fault-plane solutions derived from this 6-year record can be associated geometrically with segments of the Red Mountain, Pitas Point-Ventura, and San Cayentano faults, and perhaps the Mid-Channel fault and fault $X$ (see fig. 3). The solutions show generally near-horizontal $P$ axes oriented at an average of N. $24^{\circ} \mathrm{E}$. The inferred compressive stress is reflected in earthquakes of magnitude approximately 1 to 6.5 and reverse displacement on the east-trending faults; the average slip vector indicates approximately equal parts of vertical and left-lateral slip (Yerkes and Lee, in press).

All the evidence on the rate and sense of deformation is mutually consistent for individual segments of the faults in the Santa Barbara Channel area: geologic data on the sense of latest displacement and amount and sense of stratigraphic separation, geodetic data on tilting of coastal areas underlain by the faults, uplift of dated marine terrace deposits in such areas, and associated fault-plane solutions. The average rates of uplift (up to $10 \mathrm{~m} / 1000$ years), indicated by dating of deposits as young as 2,500 years, show no slowing over the last 45,000 years (Yerkes and Iee, in press).

The east-trending reverse faults that dominate the structure of the western Transverse Ranges may be viewed as slip surfaces between a series of north- to northeast-dipping shingles along which many kilometers of north-south shortening and east-west extension occurred in latest Quaternary time. The Santa Barbara earthquake of 13 August 1978 and its aftershock pattern fit well with this model, and its faultplane solution neatly fits those of five previously mapped events within $15 \mathrm{~km}$ of it.

\section{DATA PROCESSING AND ANALYSIS}

The Santa Barbara earthquake and its aftershocks were well recorded by the California Institute of Technology (CIT)-U.S. Geological Survey (USGS) cooperative network in southern California and by seismographic stations operated by University of Southern Califormia (USC), University of California at Santa Barbara (UCSB), and California Department of Water Resources (DWR). It is very fortunate that the USC group established four stations (three in Santa Barbara Channel) near the epicentral area one day before the earthquake. After the earthquake, additional stations were installed by USC, USGS, and others.

In order to make a study in a short time, we selected about 100 earthquakes (out of several hundred well-recorded ones) and processed mostly data recorded at the aritical stations (fig. 1). Initially, the data were processed indenendently at CIT, USGS, and USC. At CIT, the earthquakes were processed and analyzed in a routine manner using a computer-assisted system designed by $\mathrm{C}$. E. Johnson. At USC, seismic data recorded on magnetic tapes were played back at a scile of $1 \mathrm{~cm}=1$ second and arrival times were read manually. CIT's Develocorder film reccrdings of SYP station (about $30 \mathrm{~km}$ from the epicenter) were scanned at the USGS. P-arrival, S-arrival, and signal duration were measured for events of duration 20 seconds or more. From the scar list, arrival times for the larger aftershocks were read from Develoconder films that recorded the Santa Barbara Channel region stations. Overall errors in the arrival time data are gererally less than 0.1 second.

The data from these three sources were merged and analyzed. We located the exxthquakes using the HYP071 computer program (Lee and Lahr, 1975). Initially, we used Healy's (1963) crustal structure model and station delays norked out for the Western Transverse Ranges by Le?, Yerkes, and Simirenko (in press). This allowec us to eliminate gross errors in arrival times quickly. We then selected 17 well-recorded earthruakes and derived a set of station correctiors using a crustal model (fig. 2) which approximates a tentative velocity profile in Santa Barbara Channel obtained from a geophysical survey usirg the seismic-reflection method.

Station coordinates and station delays are given in table 1. Finally, we relocatef all earthquakes using this crustal model ard the station delays. Earthquakes were located on the basis of P-wave arrival times. The HYF 71 computer program employs Geiger's (1912) nrthod to determine hypocenters by minimizing the residuals between observed and calculated arrivals. Travel times from a trial hypocenter tc the stations and their partial derivatives are canputed on the assumption of a horizontal multilayer model by a technique introduced $k \rightarrow$ Eaton (1969) . Earthquake magnitudes were estimated using the signal duration method (Lee and others, 1972). However, the present earthquake. magnitude estimates are very crude and should be calibrated against the local magnitude scale originally proposed by Richter in 1935 (Richter, 1958). For example, magnitude estimated fram signal duration for the main shock (table 2) is 4.9 , whereas the average Richter magnitude cf five wood-Anderson stations is 5.1 .

\section{DISTRIBUTION OF HYPOCENTERS}

\section{A total of 71 earthquakes that occirred} from 2254 GCT August 13 to 0718 GCT Auglust 18, 1978 are listed chronologically in table 2. Included are the origin time, location of hypocenter (epicenter and focal depth), magnitude, and number of arrival times used. In addition, five parameters are listed as a means of evaluating the quality of the hypocenter solution: 
Table 1.- Coordinates and delays of principal seismographic stations used in the present study

\begin{tabular}{|c|c|c|c|c|}
\hline $\begin{array}{l}\text { Station } \\
\text { code }\end{array}$ & Latitude (N) & Longitude (W) & $\begin{array}{l}\text { Elevation } \\
\text { (m) }\end{array}$ & $\begin{array}{l}\text { Delay } \\
\text { (s) }\end{array}$ \\
\hline DCA & $34^{\circ} 18.72^{\prime}$ & $119^{\circ} 33.68^{\prime}$ & -76 & 0.28 \\
\hline DCC & $34^{\circ} 18.57^{\prime}$ & $119^{\circ} 39.35^{\prime}$ & -82 & .34 \\
\hline $\mathrm{DCE}$ & $34^{\circ} 22.00^{\prime}$ & $119^{\circ} 37.35^{\prime}$ & -46 & .04 \\
\hline PKL & $34^{\circ} 26.84^{\prime}$ & $119^{\circ} 36.98^{\prime}$ & 142 & -.39 \\
\hline VTR & $34^{\circ} 24.32^{\prime}$ & $119^{\circ} 42.85^{\prime}$ & 122 & 0.00 \\
\hline $\mathrm{SBCC}$ & $34^{\circ} 56.48^{\prime}$ & $120^{\circ} 10.32^{\prime}$ & 610 & .72 \\
\hline $\mathrm{SBCD}$ & $34^{\circ} 22.12^{\prime}$ & $119^{\circ} 20.63^{\prime}$ & 213 & .04 \\
\hline SBLC & $34^{\circ} 29.79^{\prime}$ & $119^{\circ} 42.81^{\prime}$ & 1190 & -.33 \\
\hline SBLG & $34^{\circ} \quad 6.57^{\prime}$ & $119^{\circ} \quad 3.85^{\prime}$ & 415 & -.77 \\
\hline SBLP & $34^{\circ} 33.62^{\prime}$ & $120^{\circ} 24.03^{\prime}$ & 134 & .29 \\
\hline SBSC & $33^{\circ} 59.68^{\prime}$ & $119^{\circ} 37.99^{\prime}$ & 457 & -.59 \\
\hline SBSM & $34^{\circ} \quad 2.25^{\prime}$ & $120^{\circ} 20.99^{\prime}$ & 172 & -.19 \\
\hline SBSN* & $33^{\circ} 14.70^{\prime}$ & $119^{\circ} 30.40^{\prime}$ & 259 & - \\
\hline CAM & $34^{\circ} 15.27^{\prime}$ & $119^{\circ} 1.99^{\circ}$ & 271 & .29 \\
\hline ECF & $34^{\circ} 27.48^{\prime}$ & $119^{\circ} 5.44^{\circ}$ & 1005 & .17 \\
\hline KYP* & $34^{\circ} \quad 6.10^{\prime}$ & $118^{\circ} 52.77^{\prime}$ & 701 & - \\
\hline PTD* & $34^{\circ} \quad 0.25^{\prime}$ & $118^{\circ} 48.37^{\prime}$ & 41 & - \\
\hline$S A D^{*}$ & $34^{\circ} \quad 4.88^{\prime}$ & $118^{\circ} 39.90^{\prime}$ & 727 & -- \\
\hline SIP* & $34^{\circ} 12.26^{\prime}$ & $118^{\circ} 46.92^{\prime}$ & 701 & -- \\
\hline SYP & $34^{\circ} 31.60^{\prime}$ & $119^{\circ} 58.70^{\circ}$ & 1305 & .02 \\
\hline
\end{tabular}

*These stations are located more than $80 \mathrm{~km}$ from the Santa Barbara earthquakes and were not used in the earthquake location.

(1) the largest azimuthal separation between stations $(\alpha),(2)$ epicentral distance to the nearest station ( $\beta$ ), (3) root-mean-square error of the time residuals, (4) standard error of the epicenter, and (5) standard error of the focal depth. On the basis of these parameters, the general reliability of each earthquake solution is graded as either excellent (A), good (B), fair (C), or poor (D). The criteria for these classifications are given in table 3.

A brief discussion of the accuracy of hypocenter solution of earthquakes was given by Iee, Eaton, and Brabb (1971). To obtain a reliable epicenter, the largest azimuthal separation between stations $(\alpha)$ should be less than $180^{\circ}$, so that the earthquake epicenter is surrounded by stations. To obtain a reliable focal depth, epicentral distance to the nearest station ( $\beta$ ) should be less than the focal depth, so that there is a direct ray-path. In addition, systematic errors arise from uncertainties in the crustal velocity model. These errors cannot be determined without controlled experiments, such as calibrated explosions in the focal region. owing to the irregular distribution of stations and occasional loss of data from critical stations, the quality of hypocenter solu'tions in table 2 varies. Although standard errors of epicenters and focal depth are given, they must be interpreted with caution, especially for quality $C$ and $D$ solutions. These standard errors are computed with respect to the assumed crustal velocity model, which is not necessarily a good approximation to the real earth.

The epicenter distribution (fig. 3) shows a linear trend of $\mathrm{N} .60^{\circ} \mathrm{W}$. with the main shock at the southeastern end. The dimension of the immediate aftershock area is approximitely 3 by $12 \mathrm{~km}$. The main shock was preceded four hours by a small earthquake located at the lower righthand corner of the area of figure 3 . It is not clear to us whether this earthquake is related to the Santa Barbara earthquake. However, it occurred in an area where a swarm of earthquakes took place in March and April of 1978. Immediately after the main shock, seismic antivity was 
concentrated $7 \mathrm{~km}$ northwest of the main event. Later, a few aftershocks occurred nearer to the main shock; only two aftershocks located southeast of the main shock occurred in the first five days. On August 16 a few earthquakes occurred $10 \mathrm{~km}$ south of the epicenter; they appear to be associated with a different fault.

\section{LOCATION OF THE MAIN SHOCK}

We are fortunate that the Santa Barbara earthquakes were surrounded by seismograph stations and especially that three stations were within $10 \mathrm{~km}$ of the earthquake epicenters (see fig. 1). However, most of the stations are located northeast of the earthquakes. To lessen the station-distribution bias, we employed azimuthal weighting (Lee and Lahr, 1975), ignored stations farther than $80 \mathrm{~km}$ from the earthquake location, and also assigned greater weights to stations within $40 \mathrm{~km}$ of the earthquakes.

The biggest uncertainty in earthquake location is due to our lack of knowledge of the crustal structure under the Santa Barbara Channel region. Experiments with various crustal models indicate that the epicenter error may be as high as $\pm 3 \mathrm{~km}$ and the focaldepth error $\pm 5 \mathrm{~km}$. For a given crustal model, we also experimented with different subsets of arrival-time data for the main shock. The results showed that (1) epicentral locations do not differ more than $\pm 1 \mathrm{~km}$ if the earthquake is surrounded (maximum azimuthal gap between stations less than $180^{\circ}$ ), and (2) focal depths do not differ more than $\pm 2 \mathrm{~km}$ if there is a station within $10 \mathrm{~km}$ of the earthquake. The relative location errors between different earthquakes are small because we use station corrections derived from a set of better recorded earthquakes. In view of the above discussion, we suggest the following main-shock parameters:

$$
\begin{aligned}
\text { Origin time }= & 22^{\mathrm{h}} 54^{\mathrm{m}} 52.4^{\mathrm{s}}( \pm 0.1 \mathrm{~s}) \\
\text { Epicenter }= & \begin{aligned}
34^{\circ} 22.2^{\prime} \mathrm{N} ., 119^{\circ} 43.0^{\prime} \mathrm{W} . \\
( \pm 2 \mathrm{~km})
\end{aligned} \\
\text { Focal depth }= & 12.5 \mathrm{~km}( \pm 3 \mathrm{~km}) \\
\text { Magnitude }= & \begin{array}{l}
\mathrm{M}_{\mathrm{L}}=5.1 \text { (average of five CIT } \\
\text { Wood-Anderson stations) }
\end{array}
\end{aligned}
$$

The location parameters are also supported by the strong-motion data obtained from both the USGS and the California Division of Mines and Geology (CDMG). The time interval between S-wave arrival and the initiation of recording at the accelerometer (S-trigger time) is a minimum estimate of the S-P interval because the recorder may

\begin{tabular}{|c|c|c|c|c|}
\hline $\begin{array}{c}\text { Strong-motion } \\
\text { station }\end{array}$ & $\begin{array}{l}\text { Maximum } \\
\text { accel- } \\
\text { eration } \\
\end{array}$ & $\begin{array}{l}\text { Trigger } \\
\text { time }\end{array}$ & $\begin{array}{c}\text { Computed } \\
\text { S-P } \\
\text { time } \\
\end{array}$ & Difference \\
\hline $\begin{array}{l}\text { Santa Barbara } \\
\text { Court House } \\
\text { (USGS) }\end{array}$ & $0.21 g$ & $1.9 \mathrm{~s}$ & $2.4 \mathrm{~s}$ & $-0.5 s$ \\
\hline $\begin{array}{l}\text { Univ. Calif. } \\
\text { Santa Barbara } \\
\text { North Hall } \\
\text { (CDMG) }\end{array}$ & $0.44 g$ & $3.1 \mathrm{~s}$ & $3.0 \mathrm{~s}$ & $+0.1 \mathrm{~s}$ \\
\hline $\begin{array}{l}\text { Goleta Free- } \\
\text { field (CDMG) }\end{array}$ & $0.37 g$ & $3.3 \mathrm{~s}$ & $3.7 \mathrm{~s}$ & $-0.4 \mathrm{~s}$ \\
\hline
\end{tabular}
not be triggered by the first P-wave arrival. If we adopt our main-shock location and a ratio of P-velocity to S-velocity of 1.7 , we obtain the following differences between computed S-P and observed S-trigger times:
These time differences indicate that our mainshock location and its error estimates are reasonable. In addition, the station S.C. (at

P-WAVE VELOCITY, IN KILOMETERS PE? SECOND

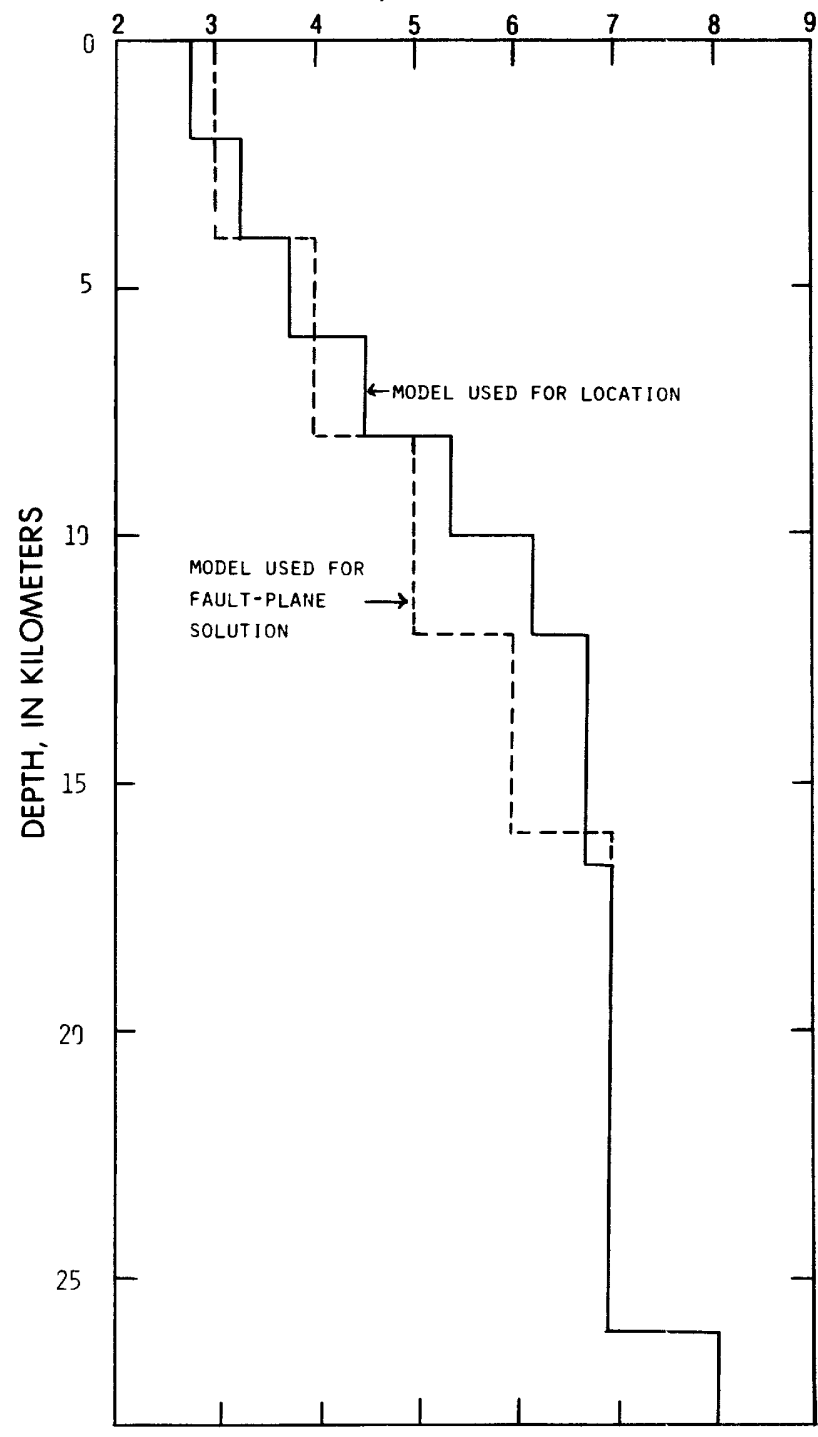

Figure 2.-Crustal structure models. 
[YEAR, MDN, DAY, HR, MN, SEC, origin time in Greenwich Civil Time (GCT). LAT N, LONG W, location of epicenter in degrees and minutes of north latitude and west longitude. DEPTH, depth of focus in kilometers. MAG, local magnitude $\left(M_{L}\right)$ of the earthquake estimated from signal durations. NO, number of stations used in locating earthquake. GAP, largest azimuthal separation in degrees between stations. DMIN, epicentral distance in kilameters to the nearest station. RMS, root-mean-square error of the time residuals: $R M S=\left[\Sigma_{i}\left(R_{i}{ }^{2} / N O\right]^{\frac{1}{2}}\right.$, where $R_{i}$ is the observed seismic-wave arrival time minus the computed time at the $i$ th station. ERH, standard error of the epicenter in kilometers: $E R H=\left[S D X^{2}+S D Y^{2}\right]^{\frac{1}{2}}$. $S D X$ and $S D Y$ are the standard errors in latitude and longitude, respectively, of the epicenter. When $N O<5, E R H$ cannot be computed and is left blank. ERZ, standard error of the focal depth in kilameters. When $N O<5, E R Z$ cannot be computed and is left blank. If $E R Z \geq 20 \mathrm{~km}$, it is also left blank. $Q$, solution quality of the hypameter (table 3) ]

\begin{tabular}{|c|c|c|c|c|c|c|c|c|c|c|c|c|c|c|c|c|}
\hline ENT & EAR & MON & DY & $\mathrm{HR}$ & MN & SEC & LAT $N$ & LONG $\mathrm{W}$ & DEPTH & MAG & NO & GAP & DMIN & RMS & ERH & ERT' \\
\hline $\begin{array}{l}1 \\
2 \\
3 \\
4 \\
5\end{array}$ & 1978 & AUG & $\begin{array}{l}13 \\
13 \\
13 \\
13 \\
13\end{array}$ & $\begin{array}{l}22 \\
23 \\
23 \\
23 \\
23\end{array}$ & $\begin{array}{r}54 \\
1 \\
1 \\
2 \\
4\end{array}$ & $\begin{array}{r}52.4 \\
0.7 \\
32.4 \\
45.6 \\
13.9\end{array}$ & $\begin{array}{l}34-22.1 \\
34-24.2 \\
34-24.8 \\
34-24.4 \\
34-23.8\end{array}$ & $\begin{array}{l}119-42.9 \\
119-46.3 \\
119-48.2 \\
119-46.2 \\
119-45.7\end{array}$ & $\begin{array}{l}12.5 \\
12.9 \\
11.9 \\
12.7 \\
12.0\end{array}$ & $\begin{array}{l}4.9 \\
2.4 \\
2.1 \\
2.7 \\
2.5\end{array}$ & $\begin{array}{r}16 \\
11 \\
8 \\
11 \\
5\end{array}$ & $\begin{array}{r}68 \\
98 \\
228 \\
68 \\
193\end{array}$ & $\begin{array}{l}4.0 \\
5.3 \\
8.2 \\
5.2 \\
4.5\end{array}$ & $\begin{array}{l}0.05 \\
0.03 \\
0.10 \\
0.05 \\
0.00\end{array}$ & $\begin{array}{l}0.2 \\
0.3 \\
2.2 \\
0.4 \\
0.2\end{array}$ & $\begin{array}{l}0.4 \\
0.2 \\
0.8 \\
0.5 \\
0.1\end{array}$ \\
\hline $\begin{array}{r}6 \\
7 \\
8 \\
9 \\
10\end{array}$ & & & $\begin{array}{l}13 \\
13 \\
13 \\
13 \\
13\end{array}$ & $\begin{array}{l}23 \\
23 \\
23 \\
23 \\
23\end{array}$ & $\begin{array}{l}5 \\
6 \\
6 \\
7 \\
8\end{array}$ & $\begin{array}{r}1.4 \\
19.0 \\
57.4 \\
30.1 \\
27.1\end{array}$ & $\begin{array}{l}34-23.1 \\
34-24.3 \\
34-24.9 \\
34-24.6 \\
34-24.3\end{array}$ & $\begin{array}{l}119-47.6 \\
119-46.3 \\
119-46.5 \\
119-46.6 \\
119-46.6\end{array}$ & $\begin{array}{r}9.1 \\
12.5 \\
12.1 \\
12.2 \\
12.4\end{array}$ & $\begin{array}{l}2.4 \\
2.1 \\
1.9 \\
2.7 \\
3.1\end{array}$ & $\begin{array}{r}10 \\
14 \\
9 \\
13 \\
13\end{array}$ & $\begin{array}{r}128 \\
68 \\
124 \\
70 \\
69\end{array}$ & $\begin{array}{r}7.7 \\
5.3 \\
5.7 \\
5.8 \\
11.7\end{array}$ & $\begin{array}{l}0.06 \\
0.05 \\
0.04 \\
0.03 \\
0.05\end{array}$ & $\begin{array}{l}0.5 \\
0.3 \\
0.5 \\
0.2 \\
0.2\end{array}$ & $\begin{array}{l}0.5 \\
0.6 \\
0.7 \\
0.4 \\
1.3\end{array}$ \\
\hline $\begin{array}{l}11 \\
12 \\
13 \\
14 \\
15\end{array}$ & & & $\begin{array}{l}13 \\
13 \\
13 \\
13 \\
13\end{array}$ & $\begin{array}{l}23 \\
23 \\
23 \\
23 \\
23\end{array}$ & $\begin{array}{l}9 \\
10 \\
11 \\
15 \\
16\end{array}$ & $\begin{array}{r}20.9 \\
9.3 \\
1.7 \\
2.5 \\
42.4\end{array}$ & $\begin{array}{l}34-24.7 \\
34-24.4 \\
34-24.3 \\
34-24.4 \\
34-24.4\end{array}$ & $\begin{array}{l}119-45.9 \\
119-48.3 \\
119-46.4 \\
119-46.4 \\
119-45.3\end{array}$ & $\begin{array}{l}12.1 \\
11.3 \\
12.8 \\
12.6 \\
11.3\end{array}$ & $\begin{array}{l}2.5 \\
2.6 \\
3.3 \\
3.0 \\
2.1\end{array}$ & $\begin{array}{r}9 \\
9 \\
12 \\
16 \\
11\end{array}$ & $\begin{array}{r}122 \\
126 \\
123 \\
68 \\
70\end{array}$ & $\begin{array}{l}4.7 \\
8.4 \\
5.5 \\
5.4 \\
3.8\end{array}$ & $\begin{array}{l}0.04 \\
0.02 \\
0.02 \\
0.11 \\
0.05\end{array}$ & $\begin{array}{l}0.5 \\
0.1 \\
0.1 \\
0.5 \\
0.3\end{array}$ & $\begin{array}{l}0.6 \\
0.2 \\
0.3 \\
1.1 \\
0.3\end{array}$ \\
\hline $\begin{array}{l}16 \\
17 \\
18 \\
19 \\
20\end{array}$ & & & $\begin{array}{l}13 \\
13 \\
13 \\
13 \\
13\end{array}$ & $\begin{array}{l}23 \\
23 \\
23 \\
23 \\
23\end{array}$ & $\begin{array}{l}18 \\
18 \\
18 \\
19 \\
22\end{array}$ & $\begin{array}{l}10.1 \\
32.0 \\
56.9 \\
42.4 \\
50.6\end{array}$ & $\begin{array}{l}34-22.9 \\
34-25.5 \\
34-23.5 \\
34-24.0 \\
34-23.3\end{array}$ & $\begin{array}{l}119-43.7 \\
119-36.2 \\
119-44.9 \\
119-44.2 \\
119-43.2\end{array}$ & $\begin{array}{r}13.4 \\
0.3 \\
13.1 \\
11.5 \\
14.3\end{array}$ & $\begin{array}{l}2.3 \\
2.1 \\
2.9 \\
1.7 \\
2.1\end{array}$ & $\begin{array}{r}13 \\
6 \\
12 \\
8 \\
8\end{array}$ & $\begin{array}{r}96 \\
96 \\
97 \\
125 \\
115\end{array}$ & $\begin{array}{r}2.9 \\
10.4 \\
3.4 \\
2.1 \\
2.0\end{array}$ & $\begin{array}{l}0.06 \\
0.15 \\
0.03 \\
0.10 \\
0.02\end{array}$ & $\begin{array}{l}0.4 \\
1.5 \\
0.2 \\
1.3 \\
0.2\end{array}$ & $\begin{array}{l}0.4 \\
2.3 \\
0.3 \\
0.7 \\
0.2\end{array}$ \\
\hline $\begin{array}{l}21 \\
22 \\
23 \\
24 \\
25\end{array}$ & & & $\begin{array}{l}13 \\
13 \\
13 \\
13 \\
13\end{array}$ & $\begin{array}{l}23 \\
23 \\
23 \\
23 \\
23\end{array}$ & $\begin{array}{l}23 \\
23 \\
30 \\
31 \\
34\end{array}$ & $\begin{array}{l}25.9 \\
53.8 \\
46.8 \\
44.9 \\
26.5\end{array}$ & $\begin{array}{l}34-24.7 \\
34-24.0 \\
34-24.8 \\
34-22.9 \\
34-24.6\end{array}$ & $\begin{array}{l}119-47.1 \\
119-44.7 \\
119-49.0 \\
119-43.1 \\
119-47.2\end{array}$ & $\begin{array}{l}12.2 \\
12.5 \\
10.7 \\
13.1 \\
13.6\end{array}$ & $\begin{array}{l}3.0 \\
2.9 \\
2.0 \\
2.0 \\
2.3\end{array}$ & $\begin{array}{r}12 \\
9 \\
12 \\
9 \\
9\end{array}$ & $\begin{array}{r}98 \\
146 \\
81 \\
114 \\
75\end{array}$ & $\begin{array}{l}6.6 \\
2.9 \\
9.5 \\
2.6 \\
6.7\end{array}$ & $\begin{array}{l}0.02 \\
0.01 \\
0.05 \\
0.02 \\
0.04\end{array}$ & $\begin{array}{l}0.1 \\
0.1 \\
0.3 \\
0.2 \\
0.3\end{array}$ & $\begin{array}{l}0.3 \\
0.2 \\
0.4 \\
0.2 \\
0.5\end{array}$ \\
\hline $\begin{array}{l}26 \\
27 \\
28 \\
29 \\
30\end{array}$ & & & $\begin{array}{l}13 \\
13 \\
13 \\
13 \\
13\end{array}$ & $\begin{array}{l}23 \\
23 \\
23 \\
23 \\
23\end{array}$ & $\begin{array}{l}35 \\
40 \\
52 \\
54 \\
56\end{array}$ & $\begin{array}{r}53.7 \\
2.5 \\
16.5 \\
52.3 \\
3.0\end{array}$ & $\begin{array}{l}34-24.4 \\
34-24.8 \\
34-23.2 \\
34-24.7 \\
34-24.5\end{array}$ & $\begin{array}{l}119-46.6 \\
119-47.5 \\
119-43.9 \\
119-48.9 \\
119-48.3\end{array}$ & $\begin{array}{r}12.7 \\
10.6 \\
10.9 \\
11.2 \\
9.8\end{array}$ & $\begin{array}{l}2.3 \\
2.6 \\
2.0 \\
2.9 \\
3.1\end{array}$ & $\begin{array}{l}12 \\
13 \\
10 \\
15 \\
13\end{array}$ & $\begin{array}{r}73 \\
75 \\
163 \\
70 \\
70\end{array}$ & $\begin{array}{r}5.8 \\
11.7 \\
2.6 \\
9.4 \\
12.9\end{array}$ & $\begin{array}{l}0.08 \\
0.04 \\
0.04 \\
0.06\end{array}$ & $\begin{array}{l}0.5 \\
0.4 \\
0.3 \\
0.2 \\
0.3\end{array}$ & $\begin{array}{l}0.8 \\
0.7 \\
0.3 \\
0.3 \\
2.4\end{array}$ \\
\hline
\end{tabular}


EVENT YEAR MON DY HR MN SEC LAT N LONG $W$ DEPTH MAG NO GAP DMIN RMS ERH ERZ $Q$

\begin{tabular}{|c|c|c|c|c|c|c|c|c|c|c|c|c|c|c|}
\hline $\begin{array}{l}31 \\
32 \\
33 \\
34\end{array}$ & $\begin{array}{l}14 \\
14 \\
14 \\
14 \\
14\end{array}$ & $\begin{array}{l}0 \\
0 \\
0 \\
0 \\
1\end{array}$ & $\begin{array}{r}14 \\
21 \\
36 \\
40 \\
2\end{array}$ & $\begin{array}{r}1.3 \\
13.5 \\
43.6 \\
10.9 \\
35.1\end{array}$ & $\begin{array}{l}34-24.0 \\
34-24.8 \\
34-24.0 \\
34-24.2 \\
34-23.9\end{array}$ & $\begin{array}{l}119-47.3 \\
119-48.8 \\
119-47.3 \\
119-46.6 \\
119-43.1\end{array}$ & $\begin{array}{l}11.4 \\
11.1 \\
12.4 \\
12.8 \\
14.1\end{array}$ & $\begin{array}{l}2.3 \\
2.9 \\
2.6 \\
2.3 \\
2.7\end{array}$ & $\begin{array}{l}14 \\
13 \\
14 \\
10 \\
15\end{array}$ & $\begin{array}{r}70 \\
127 \\
70 \\
99 \\
65\end{array}$ & $\begin{array}{l}6.9 \\
9.1 \\
6.8 \\
5.7 \\
0.9\end{array}$ & $\begin{array}{l}0.03 \\
0.03 \\
0.04 \\
0.03 \\
0.03\end{array}$ & $\begin{array}{l}0.2 \\
0.2 \\
0.2 \\
0.2 \\
0.1\end{array}$ & $\begin{array}{l}0.2 \\
0.2 \\
0.6 \\
0.4 \\
0.2\end{array}$ \\
\hline $\begin{array}{l}36 \\
37 \\
38 \\
39\end{array}$ & $\begin{array}{l}14 \\
14 \\
14 \\
14 \\
14\end{array}$ & $\begin{array}{l}1 \\
1 \\
2 \\
2 \\
4\end{array}$ & $\begin{array}{r}18 \\
24 \\
5 \\
28 \\
0\end{array}$ & $\begin{array}{r}58.6 \\
4.1 \\
19.2 \\
56.9 \\
52.9\end{array}$ & $\begin{array}{l}34-24.6 \\
34-20.6 \\
34-23.7 \\
34-23.7 \\
34-23.6\end{array}$ & $\begin{array}{l}119-47.6 \\
119-43.4 \\
119-46.8 \\
119-45.5 \\
119-44.6\end{array}$ & $\begin{array}{r}12.6 \\
9.8 \\
12.5 \\
13.3 \\
13.4\end{array}$ & $\begin{array}{l}2.2 \\
2.4 \\
1.9 \\
2.4 \\
2.4\end{array}$ & $\begin{array}{l}15 \\
14 \\
13 \\
16 \\
16\end{array}$ & $\begin{array}{l}69 \\
72 \\
70 \\
68 \\
68\end{array}$ & $\begin{array}{l}7.3 \\
6.9 \\
6.2 \\
4.2 \\
2.9\end{array}$ & $\begin{array}{l}0.04 \\
0.06 \\
0.05 \\
0.02 \\
0.03\end{array}$ & $\begin{array}{l}0.2 \\
0.3 \\
0.3 \\
0.1 \\
0.2\end{array}$ & $\begin{array}{l}0.4 \\
0.2 \\
0.6 \\
0.2 \\
0.2\end{array}$ \\
\hline $\begin{array}{l}41 \\
42 \\
43 \\
44 \\
45\end{array}$ & $\begin{array}{l}14 \\
14 \\
14 \\
14 \\
14\end{array}$ & $\begin{array}{l}5 \\
5 \\
6 \\
7 \\
7\end{array}$ & $\begin{array}{r}9 \\
22 \\
33 \\
1 \\
3\end{array}$ & $\begin{array}{l}40.5 \\
42.1 \\
26.8 \\
18.6 \\
15.3\end{array}$ & $\begin{array}{l}34-23.6 \\
34-23.4 \\
34-24.1 \\
34-24.6 \\
34-23.8\end{array}$ & $\begin{array}{l}119-44.4 \\
119-43.2 \\
119-44.3 \\
119-45.1 \\
119-45.4\end{array}$ & $\begin{array}{l}13.5 \\
13.3 \\
13.5 \\
10.0 \\
13.2\end{array}$ & $\begin{array}{l}2.2 \\
2.7 \\
2.1 \\
2.4 \\
2.2\end{array}$ & $\begin{array}{l}15 \\
13 \\
15 \\
14 \\
14\end{array}$ & $\begin{array}{r}67 \\
133 \\
66 \\
67 \\
68\end{array}$ & $\begin{array}{l}2.7 \\
1.7 \\
2.2 \\
3.5 \\
4.0\end{array}$ & $\begin{array}{l}0.02 \\
0.05 \\
0.04 \\
0.10 \\
0.03\end{array}$ & $\begin{array}{l}0.1 \\
0.3 \\
0.2 \\
0.5 \\
0.1\end{array}$ & $\begin{array}{l}0.2 \\
0.4 \\
0.3 \\
0.4 \\
0.2\end{array}$ \\
\hline $\begin{array}{l}46 \\
47 \\
48 \\
49 \\
50\end{array}$ & $\begin{array}{l}14 \\
14 \\
14 \\
14 \\
14\end{array}$ & $\begin{array}{r}7 \\
7 \\
8 \\
12 \\
16\end{array}$ & $\begin{array}{r}45 \\
47 \\
46 \\
53 \\
7\end{array}$ & $\begin{array}{l}50.6 \\
54.7 \\
51.3 \\
42.0 \\
25.3\end{array}$ & $\begin{array}{l}34-24.5 \\
34-25.0 \\
34-24.2 \\
34-24.4 \\
34-23.9\end{array}$ & $\begin{array}{l}119-48.3 \\
119-47.4 \\
119-47.4 \\
119-46.5 \\
119-45.5\end{array}$ & $\begin{array}{l}11.3 \\
13.9 \\
10.9 \\
13.5 \\
13.7\end{array}$ & $\begin{array}{l}2.3 \\
2.0 \\
3.2 \\
2.4 \\
2.5\end{array}$ & $\begin{array}{r}14 \\
13 \\
13 \\
5 \\
13\end{array}$ & $\begin{array}{r}70 \\
68 \\
70 \\
171 \\
68\end{array}$ & $\begin{array}{l}8.4 \\
7.2 \\
7.0 \\
5.6 \\
4.1\end{array}$ & $\begin{array}{l}0.04 \\
0.01 \\
0.09 \\
0.25 \\
0.04\end{array}$ & $\begin{array}{r}0.3 \\
0.1 \\
0.6 \\
11.2 \\
0.3\end{array}$ & $\begin{array}{r}0.4 \\
0.1 \\
0.7 \\
10.0 \\
0.4\end{array}$ \\
\hline $\begin{array}{l}51 \\
52 \\
53 \\
54 \\
55\end{array}$ & $\begin{array}{l}14 \\
14 \\
15 \\
15 \\
15\end{array}$ & $\begin{array}{r}16 \\
17 \\
4 \\
6 \\
9\end{array}$ & $\begin{array}{l}55 \\
25 \\
37 \\
25 \\
58\end{array}$ & $\begin{array}{r}0.5 \\
56.4 \\
12.5 \\
56.8 \\
32.1\end{array}$ & $\begin{array}{l}34-19.4 \\
34-19.4 \\
34-20.1 \\
34-20.1 \\
34-25.0\end{array}$ & $\begin{array}{l}119-49.7 \\
119-50.4 \\
119-50.6 \\
119-50.7 \\
119-47.1\end{array}$ & $\begin{array}{r}14.5 \\
9.0 \\
6.9 \\
6.5 \\
11.8\end{array}$ & $\begin{array}{l}2.3 \\
2.3 \\
2.4 \\
2.3 \\
2.3\end{array}$ & $\begin{array}{r}9 \\
9 \\
10 \\
11 \\
5\end{array}$ & $\begin{array}{r}83 \\
95 \\
135 \\
95 \\
185\end{array}$ & $\begin{array}{r}13.9 \\
14.8 \\
14.2 \\
14.4 \\
6.7\end{array}$ & $\begin{array}{l}0.08 \\
0.11 \\
0.05 \\
0.07 \\
0.06\end{array}$ & $\begin{array}{l}0.8 \\
0.8 \\
0.3 \\
0.4 \\
0.2\end{array}$ & $\begin{array}{l}3.1 \\
1.1 \\
0.4 \\
0.8 \\
0.0\end{array}$ \\
\hline $\begin{array}{l}56 \\
57 \\
58 \\
59 \\
60\end{array}$ & $\begin{array}{l}15 \\
15 \\
16 \\
16 \\
16\end{array}$ & $\begin{array}{r}15 \\
17 \\
0 \\
4 \\
5\end{array}$ & $\begin{array}{l}52 \\
16 \\
39 \\
24 \\
31\end{array}$ & $\begin{array}{r}45.5 \\
42.8 \\
33.8 \\
29.4 \\
6.0\end{array}$ & $\begin{array}{l}34-23.1 \\
34-23.7 \\
34-23.8 \\
34-21.9 \\
34-15.8\end{array}$ & $\begin{array}{l}119-48.4 \\
119-44.6 \\
119-45.3 \\
119-42.6 \\
119-43.7\end{array}$ & $\begin{array}{r}11.1 \\
13.9 \\
12.3 \\
11.6 \\
7.7\end{array}$ & $\begin{array}{l}2.1 \\
2.3 \\
2.3 \\
2.3 \\
2.5\end{array}$ & $\begin{array}{r}6 \\
9 \\
8 \\
10 \\
11\end{array}$ & $\begin{array}{r}194 \\
139 \\
98 \\
68 \\
92\end{array}$ & $\begin{array}{l}8.8 \\
3.0 \\
3.9 \\
4.4 \\
8.5\end{array}$ & $\begin{array}{l}0.12 \\
0.02 \\
0.06 \\
0.06 \\
0.04\end{array}$ & $\begin{array}{l}4.1 \\
0.3 \\
0.6 \\
0.4 \\
0.3\end{array}$ & $\begin{array}{l}2.8 \\
0.3 \\
0.9 \\
0.3 \\
0.3\end{array}$ \\
\hline $\begin{array}{l}61 \\
62 \\
63 \\
64 \\
65\end{array}$ & $\begin{array}{l}16 \\
16 \\
16 \\
16 \\
16\end{array}$ & $\begin{array}{r}7 \\
8 \\
9 \\
10 \\
11\end{array}$ & $\begin{array}{l}43 \\
57 \\
57 \\
43 \\
40\end{array}$ & $\begin{array}{l}34.8 \\
56.7 \\
28.5 \\
37.4 \\
27.9\end{array}$ & $\begin{array}{l}34-24.2 \\
34-19.7 \\
34-21.9 \\
34-23.8 \\
34-23.6\end{array}$ & $\begin{array}{l}119-46.8 \\
119-49.6 \\
119-42.5 \\
119-45.4 \\
119-45.7\end{array}$ & $\begin{array}{r}12.7 \\
8.0 \\
10.9 \\
12.8 \\
11.8\end{array}$ & $\begin{array}{l}2.1 \\
2.3 \\
2.4 \\
2.1 \\
2.8\end{array}$ & $\begin{array}{l}12 \\
11 \\
13 \\
11 \\
14\end{array}$ & $\begin{array}{l}75 \\
91 \\
68 \\
71 \\
69\end{array}$ & $\begin{array}{r}6.1 \\
13.4 \\
4.5 \\
3.9 \\
4.6\end{array}$ & $\begin{array}{l}0.05 \\
0.07 \\
0.06 \\
0.03 \\
0.04\end{array}$ & $\begin{array}{l}0.3 \\
0.3 \\
0.4 \\
0.2 \\
0.2\end{array}$ & $\begin{array}{l}0.6 \\
0.7 \\
0.3 \\
0.3 \\
0.2\end{array}$ \\
\hline $\begin{array}{l}35 \\
67 \\
68 \\
69 \\
70\end{array}$ & $\begin{array}{l}13 \\
17 \\
17 \\
18 \\
18\end{array}$ & $\begin{array}{r}1.3 \\
2 \\
12 \\
1 \\
2\end{array}$ & $\begin{array}{l}35 \\
58 \\
52 \\
55 \\
24\end{array}$ & $\begin{array}{r}11.3 \\
6.0 \\
8.0 \\
6.0 \\
21.8\end{array}$ & $\begin{array}{l}34-24.5 \\
34-23.9 \\
34-24.4 \\
34-24.5 \\
34-24.6\end{array}$ & $\begin{array}{l}119-49.3 \\
119-48.8 \\
119-46.3 \\
119-47.7 \\
119-46.4\end{array}$ & $\begin{array}{l}11.5 \\
13.8 \\
13.5 \\
12.0 \\
13.7\end{array}$ & $\begin{array}{l}3.2 \\
2.6 \\
2.1 \\
2.1 \\
1.9\end{array}$ & $\begin{array}{r}15 \\
13 \\
5 \\
11 \\
6\end{array}$ & $\begin{array}{r}71 \\
71 \\
170 \\
69 \\
169\end{array}$ & $\begin{array}{l}9.3 \\
9.1 \\
5.3 \\
7.5 \\
5.5\end{array}$ & $\begin{array}{l}0.04 \\
0.14 \\
0.15 \\
0.04 \\
0.03\end{array}$ & $\begin{array}{l}0.3 \\
0.7 \\
6.4 \\
0.2 \\
0.5\end{array}$ & $\begin{array}{ll}0.4 & A \\
1.6 & A \\
5.7 & 1 \\
0.5 & A \\
0.8 & E\end{array}$ \\
\hline 71 & 18 & 7 & 18 & 51.4 & $34-24.1$ & $119-46.0$ & 12.6 & 1 & 12 & 68 & 4.8 & 0.06 & 0.5 & .7 \\
\hline
\end{tabular}


Table 3.-Criteria for the four quality grades of $Q$

[Q is based on both the nature of the station distribution with respect to the earthquake and the statistical measure of the solution. These two factors are each rated independently. $Q$ is taken as the average of the ratings from the two schemes, for example, an A and a C yield a B, and two B's yield a B. When tre two ratings are only one level apart the lower one is used; for example, an A and a B yield a B]

\begin{tabular}{|c|c|c|c|c|c|c|c|c|}
\hline \multirow[b]{2}{*}{$\mathrm{Q}$} & \multicolumn{2}{|c|}{ Solution quality } & \multicolumn{3}{|c|}{ Station distribution } & \multicolumn{3}{|c|}{ Statistical measures } \\
\hline & Epicenter & Focal depth & NO & GAP & DMIN & RMS & ERH & ERZ \\
\hline A & Excellent- & ---Good-- - & $>5$ & $90^{\circ}$ & $\leqq$ Depth or $5 \mathrm{~km}$ & $<0.15 \mathrm{~s}$ & $<1.0 \mathrm{~km}$ & $<2.0 \mathrm{~km}$ \\
\hline B & Good----- & --Fair-- & $>5$ & $135^{\circ}$ & $\leqq 2 \times$ depth or $10 \mathrm{~km}$ & $<0.30$ & $<2.5$ & $<5.0$ \\
\hline $\mathrm{D}$ & Poor---_-- & ---Poor---- & $<5$ & $180^{\circ}$ & $>50 \mathrm{~km}$ & $>0.50$ & $>5.0$ & $>5.0$ \\
\hline
\end{tabular}

Santa Barbara Museum of Natural History and operated by CIT) gives S-P time of $2.0 \mathrm{~s}$ from its torsion and strong-motion instruments. If we include the SBC data and the above S-trigger times as S-P intervals in our location of the main shock, the epicenter differs by about $1 \mathrm{~km}$ and the focal depth by about $2 \mathrm{~km}$ from our preferred location.

\section{FOCAL MECHANISM OF THE MAIN SHOCK}

Fault-plane solutions of an earthquake can be detemined directly from the first-motion pattern of P-waves provided that (1) the earthquake is well located, (2) the emergent angles

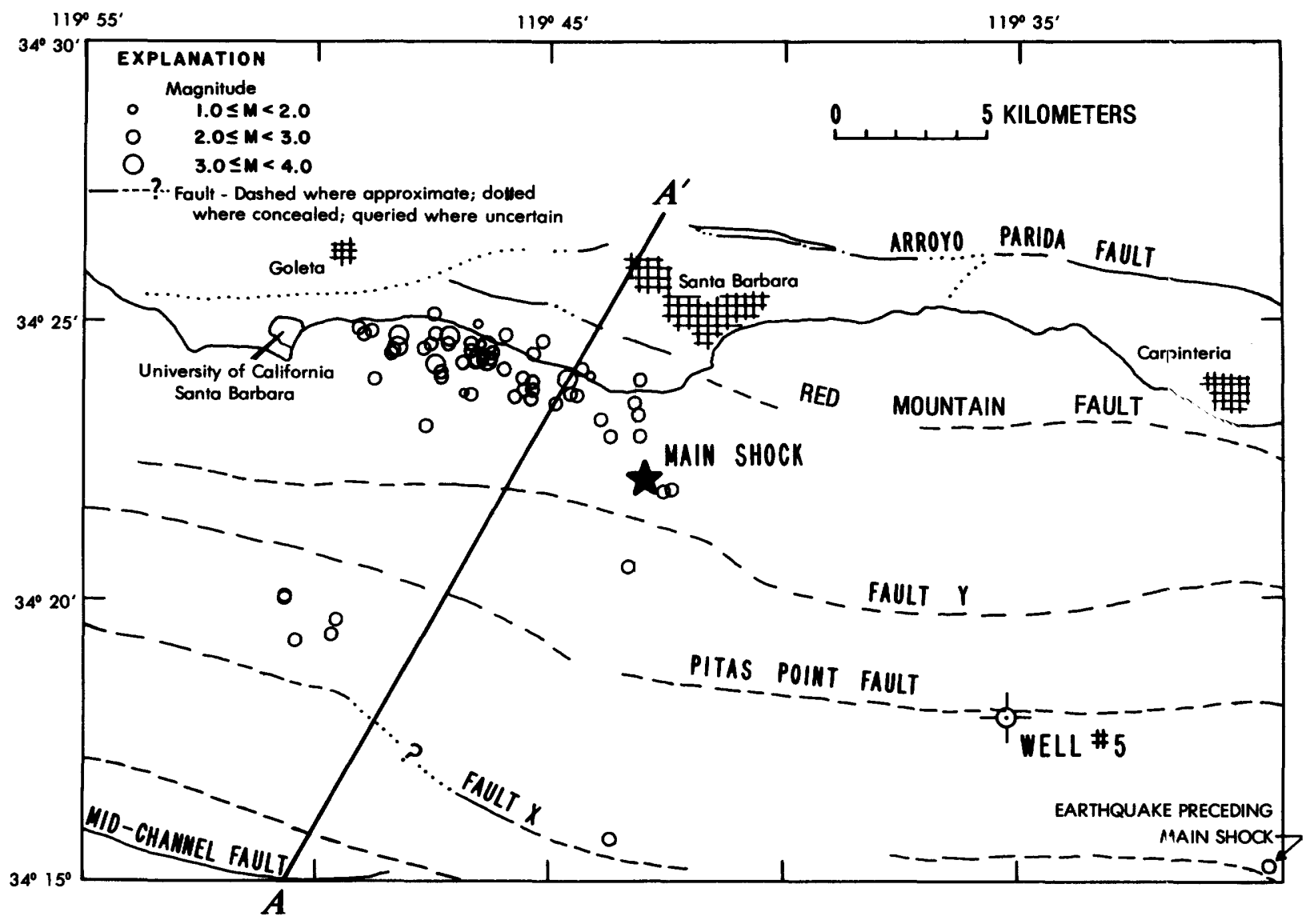

Figure 3.-Epicenters of Santa Barbara earthquake and its major aftershocks. 
of seismic waves to the stations are computed correctly from an adequate crustal model, and (3) the true polarity of the first P-motions is properly identified from seismograms. The model we used to locate the earthquakes approximates the travel times well, but it has too many arbitrarily discrete layers. Consequently, it may give an erroneous first-motion pattern. Therefore, we used a simpler crustal model (see fig. 2) for computing the first-motion pattern. Figure 4 shows our fault-plane solution of the main shock. The two possible fault planes are (1) strike $\mathrm{N}^{\circ} 66^{\circ} \mathrm{W} .$, dip $40^{\circ} \mathrm{N}$. , and (2) strike N. $22^{\circ} \mathrm{W}$., dip $60^{\circ} \mathrm{S}$. The focal mechanism indicates reverse faulting with a minor strikeslip component. The local geology and spatial distribution of the aftershocks obviously favor the N. 66 W. $-40^{\circ}$ N. fault plane, which has a minor left-lateral component. Our poor knowledge of the crustal structure precludes determination of the dip to better than $\pm 10^{\circ}$. The strike of the north-dipping fault plane is reasonably well constrained, but that of the south-dipping plane is poorly constrained. If, as in the present case, we interpret the crustal structure in tems of a simple multilayer model, then the dip of the fault plane is controlled by the first critical refraction angle of seismic rays to the intermediate-distance stations. This in turn depends on the velocity contrast between the rocks in the focal area and those immediately below. The fault dip $(\phi)$ is determined approximately by:

$$
\phi \cong 90^{\circ}-\sin ^{-1}\left(v_{1} / v_{2}\right)
$$

where $\nu_{1}$ is the layer velocity containing the earthquake focus and $v_{2}$ is the velocity of the layer next below. It is unlikely that the dip will be larger than $60^{\circ}$ because that would require $v_{2}$ to be more than twice $v_{1}$, which is unlikely because $v_{2}$ cannot be greater than $8 \mathrm{~km} / \mathrm{s}$ in the lower crust, and $v_{1}$ is probably not less than $4 \mathrm{~km} / \mathrm{s}$ at a depth of $12 \mathrm{~km}$.

\section{CORRELATION}

In an attempt to identify the fault or faults that generated the August 13, 1978 earthquake, we plotted a cross section of the earthquake hypocenters along line $A-A^{\prime}$ (fig. 3), which is perpendicular to the trend of the aftershock pattern. The result is shown in figure 5. The present data are inadequate to uniquely identify the generative fault. First, the fault may not be a uniformly dipping surface. Second, the hypocenters could be fitted to a surface dipping between $30^{\circ}$ and $75^{\circ} \mathrm{N}$. The fault-plane solution of the main shock suggests that faulting occurred on a plane dipping about $40^{\circ} \mathrm{N}$. but not greater than $60^{\circ} \mathrm{N}$.; if that plane is projected to the surface it can be correlated with fault $X$. However, geologic data in the eastern Santa Barbara Channel indicate that some structural features south of well num-

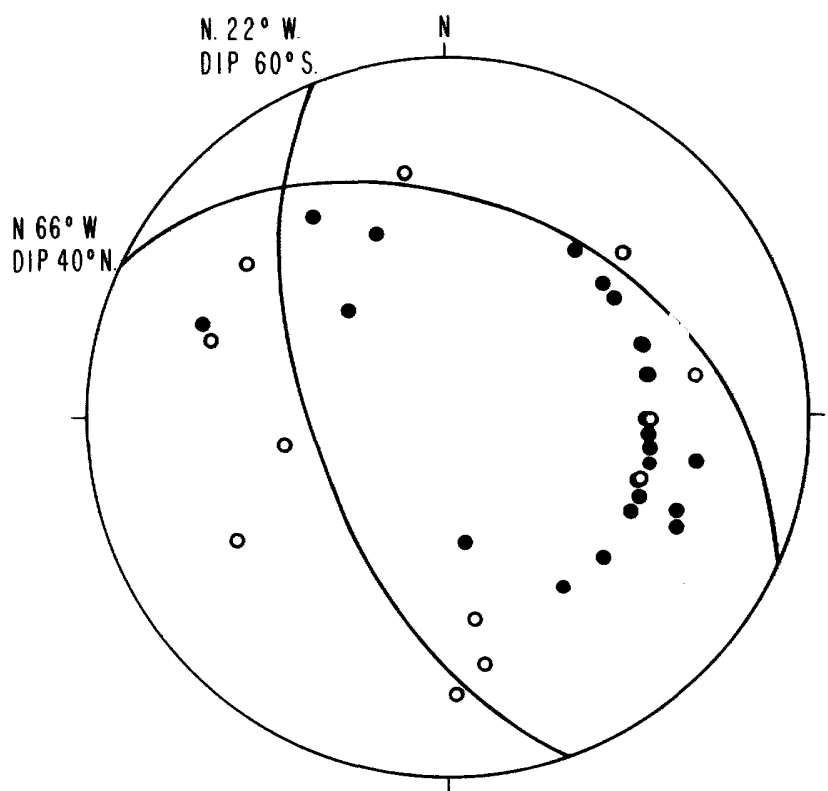

Figure 4.-Fault-plane solution of Santa Barbara earthquake.

ber 5 (fig. 3) dip south. The Pitas Point fault dips steeply north near the surface and could be the generative fault if it dips more gently at depth.

\section{CONCLUSIONS}

Preliminary results on the Santa Barbara earthquake and its major aftershocks incicate that reverse faulting took place on a ncrthdipping fault at a depth of about $12 \mathrm{~km}$ and that the rupture propagated northwest toward Goleta. This is consistent with $0.44 \mathrm{~g}$ maximum acreleration recorded by CDMG in Goleta at North Hall, University of California at Santa Barbara; most of the damage occurred in Goleta also. In addition, extension of the trend of the aftershock pattern westward intersects the shorelin? at the mouth of Telecote Canyon; severe shaking there caused failure of a long segment of unsumported railroad fill and the resulting derailment and wreck of a freight train about 7 minutes after the earthquake.

The Santa Barbara earthquake was relatively small, and there was no onshore surface nupture. The subsurface rupture progagated to the northwest. Had the earthquake been larger and rupture propagated to the southeast or a greater distance to the northwest, it could have posed a hazard to oilfield operations. It is interesting to note that the June 30, 1941 Santa Barbara earthquake was preceded by an earthquake swarm in February of 1941. Similarly, the August 13, 1978 Santa Barbara earthquake was preceded by an earthquake swarm located abo at $20 \mathrm{~km}$ toward the southeast in March and April of 1978. Ten years before, the 1968 earthquake swarm in 


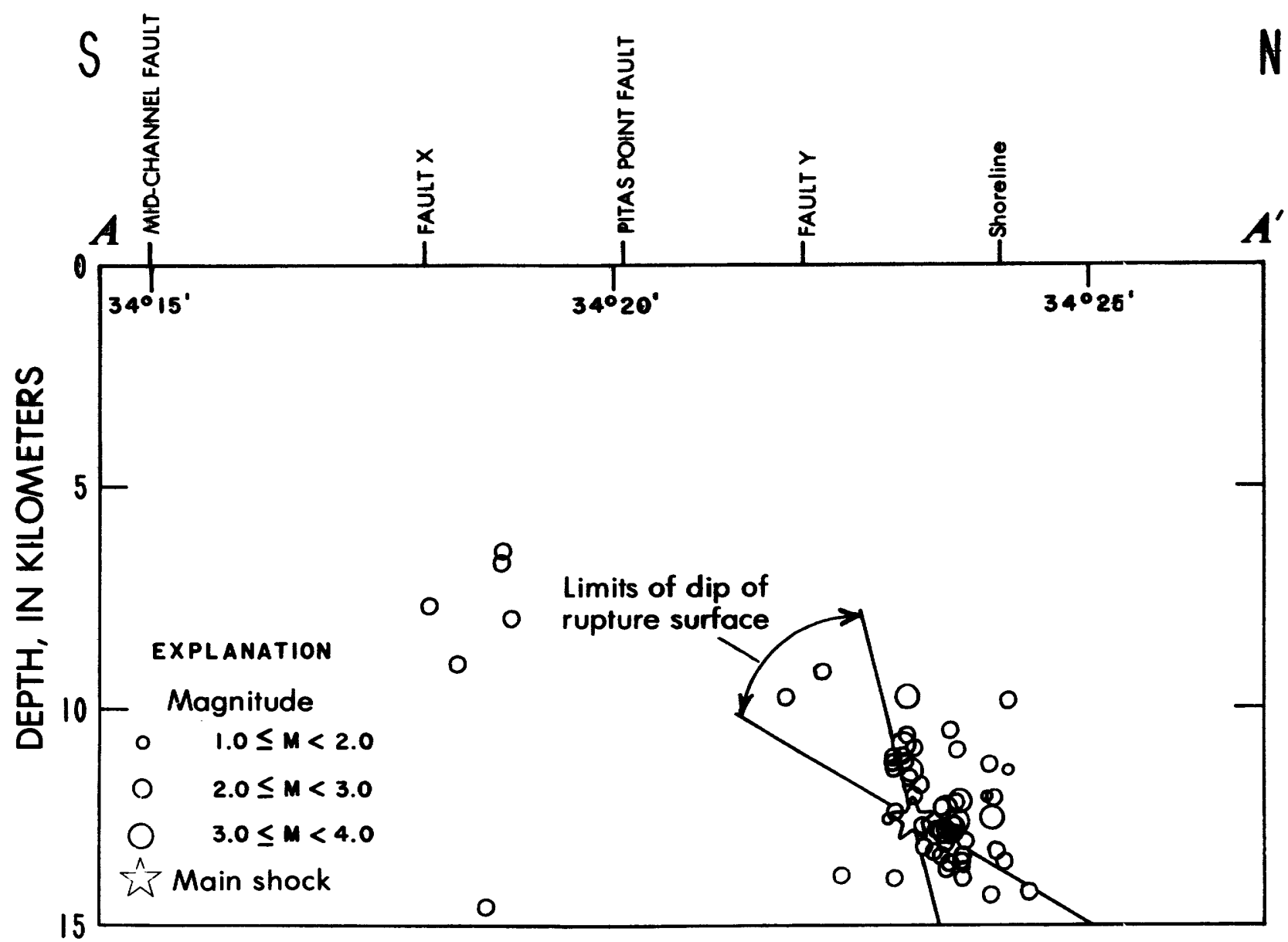

Figure 5.-Cross section of area of figure 3, showing hypocenter distributions and faults.

the Santa Barbara Channel was located in the same general area as the March-April 1978 swarm and included a magnitude 5.2 event (fig. 1) (Sylvester and others, 1970). However, this swarm was not followed by any larger earthquake. Therefore, it is not clear that earthquake swarms are reliable precursors to larger earthquakes in the Santa Barbara Channel.

\section{REFERENCES CITED}

Allen, C. R., St. Amand, P., Richter, C. F., and Nordquist, J. M., 1965, Relationship between seismicity and geologic structure in the southern California region: Seismol. Soc. America Bull., v. 55, p. 753-797.

Eaton, J. P., 1969, Hypolayer-a computer program for determining hypocenters of local earthquakes in an earth consisting of uniform flat layers over a half-space: U.S. Geol. Survey open-file report, $155 \mathrm{p}$.

Ellsworth, W. L., Campbell, R. H., Hill, D. P., Page, R. A., Alewine, R. W., III, Hanks, T. C., Heaton, T. H., Hileman, J. A., Kanamori, H. , Minster, B., and Whitoomb, J. H., 1973, Point Mugu, California, earthquake of 21 February, 1973, and its aftershocks: Science, v. 182, p. 1127-1129.
Geiger, L., 1912, Probability method for the determination of earthquake epicrnters from the arrival time only (translated from Geiger's 1910 German article) : Bull. St. Louis Univ., v. 8, p. 56-71.

Hamilton, R. M., Yerkes, R. F., Browr, R. D., Jr., Burford, R. O., and De Noyer, J. M., 1969, Seismicity and associated effects, Santa Barbara region, pt. D of Geology, petroleum development, and seismicity of the Santa Barbara Channel region, Califorria: U.S. Geol. Survey Prof. Paper 679, p. 47-68.

Healy, J. H., 1963, Crustal structure along the coast of California from seismic refraction measurements: J. Geophys. Res., v. 68, p. 5777-5787.

Hileman, J. A., Allen, C. R., and Nordquist, J. M., 1973, Seismicity of the southern California region: Contribution no. 2385, Div. of Geological and Planetary Sciences, California Institute of Technology.

Lee, W. H. K. , Bennett, R. E., and Mengher, K. L., 1972, A method of estimating magnitude of local earthquakes fron: signal curation: U.S. Geological Surver open-file report, $28 \mathrm{p}$.

Lee, W. H. K., Eaton, M. S., and Brakh, E. E. 1971. The earthquake sequence near Danville, 
California, 1970: Seismological Society of America Bulletin, v. 61, p. 1771-1794.

Lee, W. H. K., and Ellsworth, W. L., 1975, Earthquake activity in the Santa Barbara Channel region, in Draft environment statement, Oil and gas development in the Santa Barbara Channel outer continental shelf off California: U.S. Geological Survey, p. II80 - II-137.

Lee, W. H. K., and Lahr, J. C., 1975, HYPO71 (Revised) : A computer program for determining hypocenter, magnitude, and first motion pattern of local earthquakes: U.S. Geological Survey Open-file Report 75-311, $114 \mathrm{p}$.

Lee, W. H. K., Yerkes, R. F., and Simirenko, M., (in press), Recent earthquake activity and focal mechanisms in the western Transverse Ranges, California: U.S. Geological Survey Circular 799A.

Richter, C. F., 1958, Elementary seismology:
San Francisco, W. H. Freedman and Company, $768 \mathrm{p}$.

Stierman, D. J., and Ellsworth, W. L., 1976, Aftershocks of the February 21, 1973 Point Mugu, California earthquake: Seismological Society of America Bulletin, v. 66 , no. 6 , p. 1931-1952.

Sylvester, A. G., Smith, S. W., and Schol.z, C. H., 1970, Earthquake swarm in the Santa Barbara Channel, California, 1968: Seismological Society of America Bulletin, v. 60 , p. 10471060.

Yeats, R. S., Lee, W. H. K., and Yerkes, R. F., (in press), Geology and seismicity of the eastern end of the Red Mountain fault, Ventura County, California: U.S. Gsological Survey Professional Paper.

Yerkes, R. F., and Lee, W. H. K., (in press), Late Quaternary deformation in the western Transverse Ranges, California: U.S. Geological Survey Circular 799B. 
